\title{
Instructional Learning Based on Scientific Approach for Elementary School Students
}

\author{
Shofi Dwi Rakhma Dewi ${ }^{1}$, Subuh Anggoro ${ }^{2}$ \\ \{ shofidwi24@gmail.com ${ }^{1}$, subuhanggoro@ump.ac.id ${ }^{2}$ \} \\ ${ }^{1,2}$ Universitas Muhammadiyah Purwokerto
}

\begin{abstract}
This study aims to determine the magnitude of the needs of teachers and students for scientific approach-based learning media for fourth grade elementary school students. The subjects of this study were 3 teachers and 80 students in Elementary school Purbalingga District. The results of the needs analysis show that teachers still experience difficulties in implementing the 2013 curriculum. Not only that, teachers also lack scientific approach-based learning media to be used in learning activities. For this reason, it is necessary to develop learning media based on a scientific approach. The results of the study indicate that teachers and students need the development of learning media based on a scientific approach. This research went through the literature study and field studies which were carried out using interviews, and media needs questionnaires. The results of the media needs questionnaire show that $64 \%$ of respondents really need scientific approach-based learning media to help the learning process and $36 \%$ need learning media. based on the scientific approach is expected to be able to streamline the learning process using the 2013 curriculum.
\end{abstract}

Keywords: Instructional learning, scientific approach, elementary school

\section{Introduction}

Learning media is a means used by teachers to facilitate the learning process. Learning media can be textbook, e-media, and audio learning media. A good learning media will help students to build their understanding of the learning materials being studied. The purpose of media use is to apply objects that are abstract. Through the media, learners can better understand the concept and more interested in learning [1].

Media has an important role in the learning process in the classroom. Along with the development of the existing learning, media must be adapted to the curriculum applicable in schools, we need to know that curriculum is an important part of education where the curriculum there is learning planning used to achieve a learning goal [2]. Currently, the curriculum applied in Indonesia is the 2013 curriculum where the curriculum 2013 refers to the formation of student characters so not only on the ability of student knowledge only. But in reality in the field found various problems in the process of applying the curriculum 2013. Many teachers are not ready and unfamiliar in applying learning by using the 2013 curriculum.

Learning in the 2013 curriculum emphasizes the fact that teachers must be able to bring innovation in the learning process so that the learning objectives are mainly on the use of media in the learning process. However, local conditions indicate that teachers still have difficulty developing learning media, especially those related to learning in the 2013 curriculum based on a scientific approach process.

Learning in the 2013 curriculum emphasizes the scientific approach, which is a scientific approach, in the learning process the scientific approach must use appropriate scientific steps, 
according to Permendikbud No. 3 of 2014 there are five stages of the scientific approach, namely: (1) observing, (2) asking, (3) gathering information, (4) building/connecting, and (5) communicating. When used, the stages do not need to be sequential. The scientific approach in the 2013 curriculum aims to produce future generations of scientists, so that the learning steps applied follow the existing scientific steps. Learning activities such as this approach are considered difficult to apply in the learning process.

The government has often tried to innovate the 2013 curriculum that has been implemented in schools, the government also facilitates the implementation of the 2013 curriculum by providing teacher books and student books as guidance for the implementation of the curriculum learning process [3]. But the actual use of teacher books and student books alone is not enough to support the on going learning process. This were caused the material contained in the book teachers and student books very little content of the material, the teacher must found from other reference sources when will teach [3]. So, there were less optimal implementation of the curriculum 2013 in elementary school. It is indicated by the results of learning obtained by students is still not optimal [4]

To create an interesting learning process required the existence of learning media that helped learning process, because the use of this learning media serves to understanding of students into a more realistic form [1]. It is in line with the opinions expressed by Kusnandi \& Sutjipto that media is a tool that helps the learning process to achieve the learning objectives and able to facilitate learners to learn, that is by building students own knowledge [2]. This argument also supported by opinions from Miarso which stated that media use in learning, in general, is to provide a variety of stimuli to the brain, overcoming barriers to communication, overcoming classical physical limitations, enabling direct interaction with environment, generate interest and interest, and uniform observation of learners [5]. Based on some of these opinions it can be concluded that the learning media is a tool for students to understand the learning process in a more concrete.

A good learning medium is one that can form students' understanding of previously studied learning materials [4]. Learning media created to support the learning process must be tailored to the material to be studied, but it must also be consistent with. Based on the description of the problems that have been conveyed, then we know that in the learning process applying the curriculum 2013 required a learning media based on a scientific approach which is used to facilitate teachers and students in apply learning process undertaken [6]. Issues that need to be answered through this research among others: whether teachers need scientific -based learning approach in learning activities, whether students need a scientific -based learning approach in learning activities, such as what the display of learning media based on the scientific approach that is able to attract student interest in learning activities.

This study aims to find out the needs of teachers and students of learning media based on the scientific approach in Purbalingga District. And provide an illustration related display -based scientific learning approach to make it more interesting. The making of the media adapts to the learning process as well as the material being studied by the students.

\section{Method}

Research needs analysis of learning media based on the scientific approach in Primary School. Subject researchers are three teachers and 80 students from Elementary School in Purbalingga Subdistrict, Purbalingga Regency. Data collection in this study used interview data collection techniques, observation, and questionnaire media needs analysis aimed at teachers and students. The instruments used were semi-structured interview guides, observation checklist, and a semi-open questionnaire.Data were analyzed based on semi-structured 
interview guides the instrument, the instrument observation checklist, and a semi-open questionnaire media needs. Results that have been analyzed and then drawn conclusions based on the facts obtained. The data obtained in the form of quantitative data and qualitative data. Quantitative data is then converted into qualitative data.The scores obtained were then converted into qualitative data on a scale of five with reference to the formula quoted from Widoyoko in the Table 1.

Table 1. Conversion Score Assesment Scale 5

\begin{tabular}{cclc}
\hline \multicolumn{1}{c}{ Formula } & $\begin{array}{c}\text { Average } \\
\text { Score }\end{array}$ & Classification & Value \\
\hline $\mathrm{X}>\mathrm{Xi}+1,8 \mathrm{sbi}$ & $>4,2$ & Very Good & $\mathrm{A}$ \\
$\mathrm{Xi}+0,6 \mathrm{sbi}<\mathrm{X}$ & $>3,4-4,2$ & Good & $\mathrm{B}$ \\
$\leq \mathrm{Xi}+1,8 \mathrm{sbi}$ & & & \\
$\mathrm{Xi}-0,6 \mathrm{sbi}<\mathrm{X}$ & $>2,6-3,4$ & Enough & $\mathrm{C}$ \\
$\leq \mathrm{Xi}+1,8 \mathrm{sbi}$ & & & \\
$\mathrm{Xi}-1,8 \mathrm{sbi}<\mathrm{X}$ & $>1,8-2,6$ & Bad & $\mathrm{D}$ \\
$\leq \mathrm{Xi}+0,6 \mathrm{sbi}$ & & & \\
$\mathrm{X} \leq \mathrm{Xi}-1,8 \mathrm{sbi}$ & $\leq 1,8$ & Very bad & $\mathrm{E}$ \\
\hline
\end{tabular}

\section{Result and Discussion}

The results of this study obtained through interviews, observation, and questionnaire media needs for teachers and students. Need analysis is done in three schools in Purbalingga District. The result obtained is the need for scientifically based learning approach to support the learning process and assist students in understanding the material that has been studied. The use of media in the learning process is still very minimal, the teacher is only fixated on the use of teacher books and student books that are minimal material. Sometimes teachers use instructional media to support but only limited to images, or videos served by the teacher.

Based on the results of interviews with fourth grade teachers at Elementary School in District Purbalingga obtained the results that teachers are still quite difficult in applying learning by using the 2013 curriculum, this is because teachers are not familiar with thematic learning patterns, the lack of teaching materials contained in the book teachers and student books, making it difficult for teachers to convey the learning process. In addition, learning by using the 2013 curriculum requires teachers to provide innovation in the learning process as with the provision of instructional media, but time constraints, costs, and knowledge make it difficult for teachers to develop learning media that can be used in the learning process. Difficulties are not only faced by teachers, but also by students, students find it difficult to deepen learning materials because the material presented is not too deep because the learning is obtained thematically, so as to adjust to the theme being studied. It also makes it difficult for students to form concepts of learning materials that are being studied.

The result of the research was also obtained based on the observation done by the researcher, where the learning process that took place at three Elementary School at Purbalingga District actually quite conducive, the students also looked calm during the learning process took place, but on the other hand it can be seen teachers still rarely use instructional media, in teaching the teacher is only fixated on the book teachers and student books are used as a source of learning, but occasionally teachers use the image as a medium. As a result, the students look quickly bored while following the learning process, it is seen by some students who look sleepy when hearing the teacher explanation. 
Based on the questionnaire of media needs which contains questions of teacher's understanding of learning in the curriculum of 2013, 3 teachers replied that they understand the curriculum lessons of 2013, but still find it difficult to apply. Then the question of teachers' understanding of the approach scientific approach 2 teachers to answer them adequately understand and 1 teacher answered understand and they try to apply the steps in learning.

Referring to the question of learning media 3 teachers answered they rarely use a variety of learning media, they only use the media as simple as a picture or video. Then on the question of the needs of teachers to the media-based scientific approach the three teachers answered that they are in need of scientific -based learning media approach to help the learning process in the curriculum 2013 and to facilitate students in understanding the material being studied. To further facilitate the results of a semi-open questionnaire, the analysis of the needs of the development of media convertible book -based scientific approach, can be seen in the table as follows. While the results of questionnaire analysis needs of learning media based on the scientific approach that has been converted scale scores of five can be seen in the

Based on Table 2, it is obtained student data about the need for learning media based on the scientific approach that is 25 respondents gave good response and 45 respondents gave a very good response. The average score earned 35 and included in the criteria is very good. So according to the students of learning media based on scientific approach is needed in the learning process. When presented in the graph, see as follows.

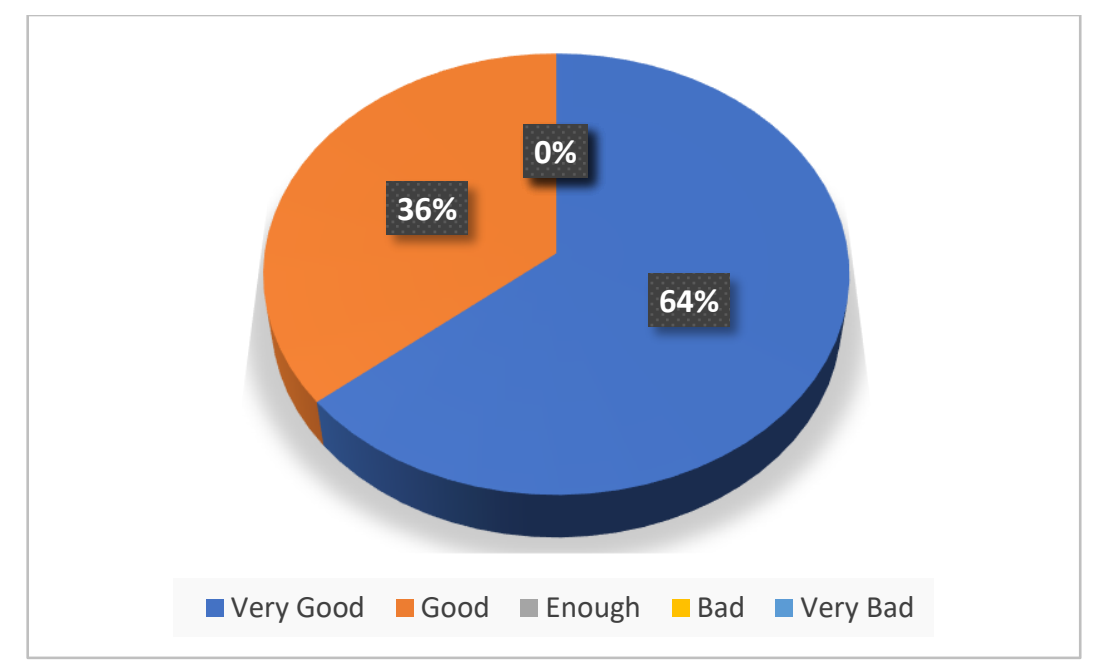

Figure 1. Student Questionnaire Result

\section{Discussion}

The purpose of learning in the 2013 curriculum is to improve students' skills both from the aspects of knowledge, improve the character and skills that exist in students. It will be realized when the learning process is going well and right. But in reality in the field of application of curriculum 2013 is still difficult to be done by teachers, especially teachers in District Purbalingga. This is felt because the material content is considered less profound and the lack of supporting learning media, especially based on the scientific approach. It needs an alternative science-based learning approach to help the learning process and build students' understanding of the material they are learning. 
Scientific-based learning media is needed to assist teachers in the learning process in accordance with the implementation of the curriculum 2013. Research was conducted by Ali et al. showed the results that the learning media needed by students and teachers in the learning process, this through which the media developed students can internalize the values of the characters with fun and add insights to interact with others [8]. So the learning media should also make students become more happy in learning, but besides the learning media must be able to convey the message values in learning. this is in line with the opinion of Naz \& Rafaqat that media is the means for transmitting or delivering[9]. Media also helps teachers to convey messages in learning to students hope that scientific-based learning media approach will be able to build students' understanding of the abstract to concrete [10]. Thus, it will certainly facilitate students in understanding learning materials.

Scientific-based learning media can be made of various types, can take the form of audio, textbook or image [9]. One alternative media-based learning scientific approach that can be used to help the learning process is a convertible book [8]. The media is designed as a companion book in addition to teacher books and student books, the convertible book is designed by adapting to the learning materials being studied, as well as adding interesting pictures with the aim of attracting students' attention to learn it. The presence of convertible book is expected to be able to add alternative learning media that can be used in learning in the curriculum 2013.

The media convertible book is designed based on a scientific approach that has the following steps [8]: (1) observing, (2) asking, (3) gathering information, (4) reasoning, and (5) communicating. is one of the approaches used in the learning process of the 2013 curriculum. This is in line with Hosnan who said that Scientific Approach is a learning process designed in such a way that students can actively build concepts, laws or principles through the stages in scientific methods such as observing, questioning, experimenting / trying, then processing data or information, presenting data or information, followed by analyzing, associating, then concluding, and creating and networking [11]. The same thing is also expressed by Kurniasih and Sani where the application of a scientific approach in learning involves process skills such as observing, classifying, measuring, predicting, explaining, and concluding [12]. Through the approach of scientific approach, students are helped to learn to build their own understanding through learning experiences that he got during the learning process took place.

Selection of convertible media based on the scientific approach that refers to the use of pictorial story as a medium of media that is able to attract students. According to Davis in Faizah, the reason for the pictorial story becomes an interesting medium for students because [4]: (a) encouraging the spirit of learning; (b) easy to find in newspapers and bookstores; (c) contains stories about everyday life; and (d) provide a variety of learning styles. The sciencebased convertible book based approach has little in common with a picture book, but the content in the convertible book is filled with learning materials and adapted to the 2013 based scientific approach curriculum.

\section{Conclusion}

Learning media based on the scientific approach for elementary school students of class IV is needed, this is in accordance with the results of teacher and student response questionnaire which states that they need alternative learning media in accordance with the content of curriculum 2013. Media-based learning scientific approach is expected to improve students' understanding of the learning materials they are learning. The overall result can be inferred teachers and students respond well their scientific media-based learning approach, as an alternative learning media that can be used and support for immediate development. Through the media convertible book -based scientific approach is expected to provide solutions to 
overcome the difficulties of teachers in applying the curriculum 2013. In addition, Media convertible book -based scientific approach, can be a companion book for teachers and students.

\section{References}

[1] Muryaningsih S, Irianto S. Math Games Domino Effect on the Results of the Learning Math Fractions in Class IV SD Negeri 1 Kalikabong. Dinamika Jurnal Ilmiah Pendidikan Dasar. 2015;7(2).

[2] Kustandi C, Sutjipto B. Media Pendidikan Manual dan Digital. Ghalia Indonesia. Bogor. 2013

[3] Hartati T, Adiredja RK. The Implementation of HOTS-based ESCOTING (Relay Writing and Collaborative Writing) Model in Writing Fable at a Primary School. Dinamika Jurnal Ilmiah Pendidikan Dasar. 2021 Apr 1;13(1):45-51.

[4] Faizah U. Keefektifan cerita bergambar untuk pendidikan nilai dan keterampilan berbahasa dalam pembelajaran Bahasa Indonesia. Jurnal Cakrawala Pendidikan. 2009;3(3).

[5] Miarso, Y. Teknologi komunikasi pendidikan. Rajawali Press. Jakarta. 2006.

[6] Redhiana D. Pengembangan Kurikulum Pada Aspek Ilmu Pengetahuan dan Teknologi yang Berbasis Lingkungan Hidup Melalui Pendekatan Saintifik di Sekolah Dasar. Dinamika Jurnal Ilmiah Pendidikan Dasar. 2014;6(2).

[7] Widoyoko EP. Evaluasi program pembelajaran panduan praktis bagi pendidik dan calon pendidik. Pustaka Pelajar. Yogyakarta. 2009.

[8] Mustadi A, Suhardi S, Susilaningrum ES, Ummah R, Wijayanti PE, Purwatiningtyas M. Character-based reflective picture storybook: Improving students' social self-concept in elementary school. Routledge; 2018 Sep 25.

[9] Naz AA, Akbar RA. Use of media for effective instruction its importance: some consideration. Journal of elementary education. 2008 Jan;18(1-2):35-40.

[10] Scarratt E, Davison J, editors. The media teacher's handbook. Routledge; 2012 Mar 15.

[11] Hosnan. (2014). Pendekatan Saintifik dan Kontekstual dalam Pembelajaran Abad 21. Bogor: Ghalia Indonesia

[12] Kurniasih I, Sani B. Implementasi kurikulum 2013: konsep \& penerapan. Kata Pena; 2014. 